TAPROBANICA, ISSN 1800-427X. December, 2013. Vol. 05, No. 02: pp. 124-130.

(C) Taprobanica Private Limited, 146, Kendalanda, Homagama, Sri Lanka.

http://www.sljol.info/index.php/tapro

\title{
PSYCHOPHILOUS AND MELITTOPHILOUS POLLINATION SYNDROME IN Tridax procumbens L. (ASTERACEAE)
}

${ }^{1}$ Department of Environmental Sciences, Andhra University, Visakhapatnam 530 003, India E-mail: ajsraju@yahoo.com²

\begin{abstract}
Tridax procumbens exhibits explosive flowering during June-September while sporadic flowering at other times. In the capitula, the florets are of two types, nectarless female ray florets and nectariferous bisexual disc florets. The disc florets are sucrose-dominant with sugar concentrations of $20 \%$ and the energy yield is optimal. The nectar contains five essential and ten non-essential amino acids. The capitula attract butterflies, bees, flies and thrips. The butterflies, while collecting nectar, and bees, while collecting nectar and pollen, effect pollination. Thrips use flower buds for breeding and effect pollination while feeding on pollen and nectar. The study suggests that $T$. procumbens exhibits psychophilous and melittophilous pollination syndrome. The work presented in this paper on plantbutterfly interactions assumes importance in the context of planning for and setting up butterfly parks.
\end{abstract}

Key words: Medicinal herb, insects, forage, pollinator, entomophily, ligulate, tubular, India

\section{Introduction}

Barkely et al. (2006) reported that Asteraceae consists of more than 22,750 species spread among some 1620 genera distributed throughout the world, and are most common in arid and semi-arid regions of subtropical and lower temperate latitudes. The species are herbs, shrubs or less commonly trees and are characterized by having the flowers reduced and organized into an involucrate pseudanthium in the form of a head or capitulum. The flowers are of two basic types: those with tubular actinomorphic corollas and those with strap-shaped or radiate zygomorphic corollas, often within the same head. Either type may be bisexual or unisexual. Many species of this family are pollinated by insects but anemophily is present in a few species. Powell (1965) mentioned that Tridax is a genus of about 26 species distributed in tropical America but only one species, T. procumbens, is widespread and grows like a weed. Balasubramanian (1989) reported on the interaction of butterflies with T. procumbens. In this plant species, flowering is explosive 
following the onset of the southwest monsoon season during which the larval food plants of the butterflies put forth fresh foliage. As a result, there is a marked increase in the abundance of adult butterflies. He recorded that several butterflies visit the flowers for nectar but details of relationship between the plant and butterflies were not provided by him or by other workers until now. Therefore, the present study was contemplated with the objective of providing complete details of floral biology, nectar characteristics and pollination in $T$. procumbens with reference to the foraging activity of butterflies and other insects.

\section{Material and Methods}

Tridax procumbens is a common medicinal herb distributed throughout India. In Visakhapatnam region $\left(17^{\circ} 42^{\prime} \mathrm{N}, 82^{\circ} 18^{\prime} \mathrm{E}\right)$ in Andhra Pradesh State, India, the plant is an important constituent of low ground vegetation and shows prolific growth during rainy season. The plants occurring here were used for study during 2010-2012. Observations regarding the organization of inflorescences, the spatial positioning of flowers, and their position on the plant were made since these features are regarded as important for effecting pollination by foragers. Life time of individuals of two floret types was recorded by marking twenty just open florets each and following them until abscission. Anthesis was initially recorded by observing ten marked mature capitula in the field. Later, the observations were repeated five times on different days, each day observing twenty marked mature capitula in order to provide accurate anthesis schedule. Twenty mature disc florets were followed for recording the time of anther dehiscence. The presentation pattern of pollen was also investigated by recording how anthers dehisced and confirmed by observing the anthers under a 10x hand lens. The details of flower morphology, such as flower sex, shape, size, colour, odour, sepals, petals, stamens and ovary, were described.

Twenty mature but un-dehisced anthers from disc florets were collected from five randomly chosen plants and placed in a Petri dish. The pollen output per anther/disc floret and pollenovule ratio was calculated using the protocol given by Cruden (1977). Individual volumes of nectar were recorded for twenty five disc florets and then the average volume of nectar per disc floret was determined and expressed in $\mu 1$. The capitula used for this purpose were bagged at mature bud stage, opened after anthesis and squeezed nectar from each disc floret into micropipette to measure the volume of nectar. Based on nectar volume in individual disc florets, the total volume of nectar secreted in a capitulum was estimated. Similarly, the nectar sugar concentration at capitulum level was determined using a Hand Sugar Refractometer (Erma, Japan). Nectar analysis for sugar types was done as per the Paper Chromatography method described in Dafni et al. (2005). The sugar content/flower is expressed as the product of nectar volume and sugar concentration per unit volume, $\mathrm{mg} / \mu \mathrm{l}$. This is done by first noting the conversion value for the recorded sugar concentration on the refractometer scale and then by multiplying it with the volume of nectar/flower. Table 5.6, given in Dafni et al. (2005), was followed for recording the conversion value to $\mathrm{mg}$ of sugars present in one $\mu 1$ of nectar. The protocols given in Sadasivam \& Manickam (1997) were followed for the quantitative estimation of sucrose, glucose and fructose in $\mathrm{mg} / \mathrm{disc}$ floret/capitulum. Dinitrosalicylic acid method was followed for the first two sugar types while Resorcinol method for the last sugar type. The caloric reward of nectar/flower/day was measured as per the formula given in Heinrich (1975). He assumed that $1 \mathrm{mg}$ of sugar yields 16.74 joules or 4 calories of energy and accordingly he used the formula for calculating the caloric reward of the nectar.

$$
\frac{\begin{array}{c}
\text { nectar volume } \\
(\mu \mathrm{l})
\end{array}}{100} \times \begin{gathered}
\text { concentration } \\
\text { of nectar }(\%)
\end{gathered} \times 16.74
$$

Baker \& Baker's (1982) method was followed for the calculation and classification of sugar ratios of nectar in disc florets. The classification gives four classes of nectar: (a) sucrose-dominant when the sucrose/glucose + fructose ratio is greater than 0.999 , (b) sucroserich for nectars with ratios between 0.5-0.999, (c) hexose-rich for those with ratios between 0.1 and 0.499, and (d) hexose-dominant for those with ratios less than 0.1. Paper chromatography method described in Dafni et al. (2005) was followed for identifying the amino acid types in the nectar of disc florets. Lowry et al. (1951) method was followed for 
measuring protein content in the nectar of disc florets.

The flower visitors were collected and identified by consulting representative specimens available at the Department of Environmental Sciences, Andhra University, Visakhapatnam. All butterflies were confirmed by consulting the books of Kunte (2007) and Gunathilagaraj et al. (1998) while other insects were variously identified to species or merely to genus. Thrips could not be identified. The insects were observed carefully for ten hours in a day for fifteen days in different months each year during profuse flowering period. The hourly foraging visits of each species were recorded on ten different days for which thirty capitula were selected. The data obtained was used to calculate the percentage of foraging visits made by each species per day and also to calculate the percentage of foraging visits of each category of insects per day. Simultaneously, the insects were observed for their foraging behavior such as mode of approach, landing, probing behaviour, the type of forage they collected, contact with essential organs to promote pollination, and inter-plant foraging activity. The butterflies were captured from the flowers during 1000-1200h on five different days for pollen analysis in the laboratory. For each butterfly species, ten specimens were captured and the proboscides were separated for examination to record whether they carry pollen grains or not. The proboscides were washed first in ethyl alcohol and the contents stained with aniline-blue on a glass slide and observed under a microscope to count the number of pollen grains present. Plant and flower details together insect foraging activity on flowers were photographed with Nikon D40X Digital SLR (10.1 pixel) and TZ240 Stereo Zoom Microscope with SP-350 Olympus Digital Camera (8.1 pixel). Magnus Compound Microscope, 5x, 10x, 40x and 100x magnification was used for studying the pollen characteristics.

\section{Results}

Flowering phenology and flower morphology: Tridax procumbens is a semi-prostrate annual or short-lived perennial herb. It may be observed throughout the year if the soil is sufficiently wet. The flowering also can occur throughout the year with explosive flowering during the rainy season from June-September.
An individual plant produces several solitary capitula over a period of four to five months. The inflorescence is a solitary heterogamous head or capitulum with two types of flowers ligulate or ray florets at the periphery and tubular or disc florets in the center of the receptacle. A capitulum produces a fixed number of six ray florets and an average of 42 disc florets; all ray and disc florets anthese within a span of four to five days. The ray florets are female and disc florets bisexual with zygomorphic symmetry. In both flower sexes, the calyx is reduced to pappus represented by hairs. In ray florets, the corolla is formed of three petals while in disc florets the corolla is tubular with five teeth at the tip. In disc florets there are five epipetalous stamens with the anthers united to form a syngenisious condition. The anther has its connective prolonged into a hood. The anthers tend to separate when the flower withers. The ovary in the florets is bicarpellary, syncarpous, and unilocular with one basal ovule. The style is surrounded by the nectary at the base and terminally forked into two parts. The stylar branches are receptive on the inner surface.

Floral biology: The ray and disc florets open during 0600-0700 h. The ray-florets open first while the disc florets open concentrically inwards on successive days. The ray florets are white while disc florets are yellow. The disc florets are protandrous with anther dehiscence taking place during the mature bud stage. The narrow anthers are united to form a hollow space into which pollen is liberated. At bud stage the style lies below the anthers, its forked arms are converged at this stage and gradually diverge. After anther dehiscence the style passes through the dehisced anthers; in this process the inner receptive surface of forked style is coated with pollen grains. The stylar arms spread out after emerging above the anthers, so that the receptive surface receives the pollen from another floret. The pollen grains are bright yellow, oblate-spheroidal, tricolporate, $21.1 \pm 0.34 \mu \mathrm{m}$ in size, and the tectum is echinate. The pollen grains average 93 per anther and 420 per flower. The pollenovule ratio is $420: 1$. The nectary located at the base of ray and disc florets is an oval, yellowish-glandular mass, with 8-12 openings at the top. The ray florets are nectarless while disc florets are nectariferous. A disc floret produces $0.21 \pm 0.05 \mu$ l of nectar which rises 
up as it accumulates in the floret. The total nectar volume per a capitulum is $9.36 \mu \mathrm{l}$. At the capitulum level, the nectar sugar concentration is $20 \pm 1.63 \%$, the sugar content $2.024 \mathrm{mg}$, and the total sugar energy 31.337 joules. The sugar types in the nectar include sucrose, glucose and fructose; their quantity per disc floret varies with sugar type. In disc florets, the sucrose is $0.05 \mathrm{mg}$, glucose $0.023 \mathrm{mg}$ and fructose 0.024 $\mathrm{mg}$. The corresponding values for sugars at capitulum level are $2.30 \mathrm{mg}, 1.061 \mathrm{mg}$ and 1.11 $\mathrm{mg}$ respectively. The nectar is sucrosedominant and the sugar ratio is 1.063 per disc floret and 1.059 per capitulum. The nectar contains five essential and ten non-essential amino acids. The essential amino acids are arginine, histidine, lysine, threonine, and valine. The non-essential amino acids include alanine, amino-butyric acid, cysteine, cystine, glutamic acid, glycine, hydroxyproline, proline, and serine. The protein content in the nectar is $0.0078 \mathrm{mg} /$ disc floret and $0.34 \mathrm{mg}$ per capitulum. The ray florets last three or four days while the disc florets four or five days.

Foraging activity: The ray florets attract the flower visitors while disc florets provide the forage for the visiting insects. The disc florets were visited during day by butterflies for nectar collection and by other insects for pollen and/or nectar collection. The butterflies included 27 species representing Papilionidae, Pieridae, Nymphalidae, Lycaenidae and Hesperiidae (Table 1). The Papilionidae and Lycaenidae each was represented by five species, Pieridae by four species, Nymphalidae by 12 species and Hesperiidae by one species. The papilionids were Pachliopta aristolochiae, $P$. hector, Papilio demoleus, $P$. polytes, and Graphium agamamnon. The pierids were Catopsilia pomona, C. pyranthe, Eurema hecabe, and Cepora nerissa. The nymphalids were Hypolimnas misippus, Phalanta phalantha, Ariadne merione, Acraea violae, Junonia lemonias, J. almana, J. hierta, Precis iphita, Tirumala limniace, Danaus chrysippus, D. genutia, and Euploea core. The lycaenids were Jamides celeno, Castalius rosimon, Zizula hylax, Chilades pandava, and Freyeria trochylus. The lone hesperiid was Borbo cinnara. Of these, the hesperiid butterfly foraged from 0700 to $1500 \mathrm{~h}$ while the butterflies belonging to all other families foraged from 0700 to $1700 \mathrm{~h}$. Of these, nymphalid individuals foraging at the florets were found to be more frequent visitors than those of other families throughout the flowering season. The foraging activity of these butterflies did not show a definite pattern but the foraging was intense during forenoon period for all butterfly species. This foraging trend was observed almost throughout the flowering season for butterflies of all families recorded in this study. The data collected on the foraging visits of butterflies of each family showed that nymphalids made $46 \%$, papilionids $20 \%$, lycaenids $17 \%$, pierids $14 \%$ and hesperiids $3 \%$ of total visits.

Table 1: List of insects foraging for the nectar/pollen of Tridax procumbens

\begin{tabular}{|c|c|}
\hline Family & Scientific name \\
\hline \multicolumn{2}{|l|}{ Hymenoptera } \\
\hline \multirow{8}{*}{ Apidae } & Apis dorsata \\
\hline & Apis cerana \\
\hline & Apis florea \\
\hline & Trigona iridipennis \\
\hline & Ceratina viridissima \\
\hline & Ceratina simillima \\
\hline & Ceratina sp. \\
\hline & Thyreus histrio \\
\hline \multicolumn{2}{|l|}{ Diptera } \\
\hline Syrphidae & Helophilus sp. \\
\hline Bombyliidae & Hyperalonia suffusipennis \\
\hline \multicolumn{2}{|l|}{ Lepidoptera } \\
\hline \multirow{5}{*}{ Papilionidae } & Pachliopta aristolochiae \\
\hline & Papilio polytes \\
\hline & Pachliopta hector \\
\hline & Graphium agamemnon \\
\hline & Papilio demoleus \\
\hline \multirow{4}{*}{ Pieridae } & Catopsilia pomona \\
\hline & Catopsilia pyranthe \\
\hline & Eurema hecabae \\
\hline & Cepora nerissa \\
\hline \multirow{12}{*}{ Nymphalidae } & Acraea violae \\
\hline & Phalanta phalantha \\
\hline & Ariadnae merione \\
\hline & Junonia lemonias \\
\hline & Junonia hierta \\
\hline & Junonia almana \\
\hline & Precis iphita \\
\hline & Hypolimnas misippus \\
\hline & Tirumala limniace \\
\hline & Danaus chrysippus \\
\hline & Danaus genutia \\
\hline & Euploea core \\
\hline \multirow{5}{*}{ Lycaenidae } & Castalius rosimon \\
\hline & Zuzula hylax \\
\hline & Freyeria trochylus \\
\hline & Chilades pandava \\
\hline & Jamides celeno \\
\hline Hesperiidae & Borbo cinnara \\
\hline
\end{tabular}


The butterflies with varying proboscis lengths were found to access nectar in the tubular florets with great ease. The florets clustered in the capitula provide convenient landing place for butterflies and also this arrangement enables them to probe several flowers in each visit in succession before departure. The flowering heads borne terminally stand out prominently and the butterflies were found to be attracted to them even from a long distance. After alighting, the butterflies balance and anchor themselves to the flower head with the help of legs and then extend the proboscis. The uncoiled proboscis is thrust into the florets to suck the nectar and pollen grains effectively dust the proboscis tip, legs, head, thorax, antenna, and abdomen. Their probing behaviour was found to achieving pollination. A sample of five specimens of each butterfly species was used to examine the pollen carrying capacity of their proboscides. The results indicated that the proboscides invariably contained pollen grains ranging from $15-35$ in papilionids, $14-23$ in pierids, 29-189 in pymphalids, 8-17 in lycaenids, and 9-21 in hesperiids. They frequently moved between individual plants of Tridax procumbens; this inter-plant foraging activity within the patch and between patches situated nearby and far away was considered to be important in crosspollination.

Other insect foragers included bees (Hymenoptera) and flies (Diptera) (Table 1). The bees were Apis cerana, A. florea, Trigona iridipennis, Ceratina viridissima, and Thyreus histrio (Apidae). The flies were Hyperalonia suffusipennis (Bombyliidae) and Helophilus sp. (Syrphidae). All bees except T. histrio were regular foragers. Thyreus histrio and the flies were not regular and consistent foragers. Thrips were not identified but they represented two species. Both bees and flies collected nectar; Apis and Trigona bees also collected pollen. They probed the disc florets for nectar and/or pollen and in so doing they contributed to pollination. Thrips were found to breed in disc florets and mature buds so that at anthesis several thrips are present. They were found to feed on nectar and pollen. The nectar is present in traces in the disc florets which were found with thrips while those florets free of thrips nectar was found in slightly measurable quantity. The disc florets with traces of nectar were found to compel the butterflies and other insects to make multiple visits to get nectar to the required levels. Such a situation was considered to be important for increasing crosspollination rate.

\section{Discussion \\ Balasubramanian (1989) reported on the interaction of butterflies with Tridax procumbens. He documented that the flowering is explosive in this plant following the onset of southwest monsoon season during which the larval food plants of the butterflies put forth fresh foliage. As a result, there is a marked increase in the abundance of adult butterflies. In the present study also, such an explosive flowering was evident during June-September and a wide array of butterflies were found to occur in search of nectar. The confinement of explosive flowering to rainy season could be attributed to increased levels of soil moisture; flowering also occurs outside this period if the soil is sufficiently wet.}

Burkhardt (1964) and Faegri \& van der Pijl (1979) characterized the butterfly-flowers relationship. Flowers conforming to this type usually possess large, white, pink, red, yellow or blue, narrow, tubular flowers with deep nectaries and often yellow rings or other markings on the petals which function as nectar guides. In Tridax procumbens, the attraction unit for foragers is the capitulum which is supported by a long stalk. In the capitula, several florets are aggregated and oriented vertically. Both ray and disc florets attract butterflies since the capitulum serves as an excellent platform for them to probe florets. Baker \& Baker (1983) also stated that such butterfly-flowers also attract bees, especially short-tongued ones. Further, these authors mentioned that short-tubed flowers tend to be hexose-rich but the nectar of $T$. procumbens is sucrose-dominant which could be attributable to non-exposure of nectar due to a narrow corolla tube and each floret is surrounded by other florets within the same capitulum. Cruden et al. (1983) documented that the nectars of most butterfly-pollinated flowers fall within the range of 15 to $25 \%$ sugar concentration. Kingsolver \& Daniel (1979) suggested that the nectar sugar concentrations of 20-25\% optimize the net energy gain by the butterflies. These generalizations are true with $T$. procumbens in which the nectar sugar concentration is $20 \%$. Further, the nectar 
energy yield is in considerable joules and is profitable for the foragers.

Nectar is a potential source of amino acids for the nutrition of insects. They require ten essential amino acids (threonine, valine, methionine, leucine, iso-leucine, phenylalanine, lysine, histidine, arginine, and tryptophan) but all of them are not normally found in all nectars. Usually, three to four essential amino acids and several non-essential ones are found in floral nectars (DeGroot, 1953; Baker and Baker, 1982; 1983). The nectar of $T$. procumbens is a source of five essential amino acids, arginine, histidine, lysine, threonine and valine and of ten non-essential ones namely, alanine, amino-butyric acid, cysteine, cystine, glutamic acid, glycine, hydroxyproline, proline and serine. Further, it is also a source of protein but it is almost negligible. The plant being a year-long bloomer is very important as nectar source for all the foragers.

Tridax procumbens as a weed produces numerous capitula and each capitulum produces several florets with nectar and pollen rewards. The capitula standing on long stalks are quite distinct and attract butterflies, bees, flies and thrips. The plant attracts butterflies belonging to all families of Lepidoptera but nymphalids are more diverse than other families. The aggregated arrangement of florets in capitula enables the visiting butterflies to reduce flight time and search time and hence each such visit paid by them is energetically rewarding. Individual capitula remain in place for about ten days out of which the anthesis of all florets occurs in a time span of four or five days. Such an extended period of capitula with aged disc florets intact and lacking nectar reward benefits the plant to enhance the attraction of capitula to butterflies. Since the florets possess short and narrow corolla tube and their arrangement is close to each other, the butterflies require skill to carefully insert the proboscis into each floret in order to access nectar. The butterflies are known to have this skill and exhibit the same while collecting nectar. In such an act, they effect pollination and the same is confirmed by pollen recovered in the washings of their proboscides. Balasubramanian (1989) reported that the florets of $T$. procumbens change colour from yellow to pale yellow to white over a period of four days. The yellow state of florets is the indicator of fresh and abundant nectar while pale florets are indicators of the absence of nectar and hence are not attractive to butterflies. He also reported that the flowers heads which are not visited by butterflies continue to remain yellow until the third or fourth day while other heads, which are visited by butterflies, turn pale yellow. With these observations, he suggested that there is a close relation between the colour change and butterfly visit. He gave a small list of butterflies visiting this plant and they belong to Pieridae, Nymphalidae and Lycaenidae only. The present study indicated that the capitula do not show color change of their florets throughout their life and butterflies visit both rewarding and unrewarding florets suggesting that they lack discriminatory power to avoid unrewarding florets. Since the capitula are long-lived, the butterflies exhibit nectar feeding activity throughout the day and the relationship between the plant and butterflies suggests psychophily.

Tridax procumbens also attracts bees consistently. The capitula provide spacious landing platform for them and their visits are energetically profitable and, in return, they provide the service of pollination. Since bees require high energy resources, they visit different capitula in quest of more pollen and nectar and in the process promote crosspollination. Among bees, one bee-fly, Thyreus histrio, as an occasional nectar forager, also effects both self- and cross-pollination. Therefore, T. procumbens is also melittophilous.

Tridax procumbens also attracts occasional visits of flies to its capitula but they are inappropriate foragers. Thrips use the flower buds for breeding and emerge from the anthesing flowers. They are resident foragers and feed on both pollen and nectar. Their nectar feeding activity decreases the standing crop of nectar at capitulum, and population level, and in effect compels the appropriate foragers to pay multiple visits to the available capitula which eventually results in the promotion of cross-pollination. Entomophily appears to be the characteristic not only of Tridax but also of many members of Asteraceae. Further, anemophily may also occur in a few species (Barkely et al., 2006). 


\section{Recommendations}

Tridax procumbens is well adapted for the occupation of disturbed habitats having several adaptive life-history characteristics such as rapid colonization of disturbed successional habitats, high reproductive rates, early and continuous reproduction, and rapid somatic growth. It utilizes butterflies and other insects for pollination and subsequent seed set. Tridax procumbens is especially important for certain butterflies of Lepidoptera. The interactions observed between the plants and butterflies, bees and other insects in this study are mutualistic and such associations are important for the sustainability of both the partners. This information should be useful in the creation of butterfly parks or gardens as well as in planning the eco-restoration programmes. In recent years, ecotourism is being promoted to create awareness about the importance of biodiversity, especially butterfly diversity. Keeping this in view, the list of plants with which the adult butterflies are associated for nectar collection is to be prepared based on intensive field studies.

\section{Literature Cited}

Baker, H. G. and I. Baker, 1982. Chemical constituents of nectar in relation to pollination mechanisms and phylogeny. Pp 131-171. In: Nitecki, M. H. (ed.). Biochemical Aspects of Evolutionary Biology. The University of Chicago Press, Chicago.

Baker, H. G. and I. Baker, 1983. Floral nectar sugar constituents in relation to pollinator type. Pp. 117-141. In: Jones, C. E. and R. J. Little (eds.). Handbook of Experimental Pollination Biology. Scientific and Academic Editions, New York.

Balasubramanian, M. V., 1989. Studies on the ecology of butterfly pollination in South India. Annals of Entomology, 7: 31-41.

Barkely, T. M., L. Brouillet, and J. L. Strother, 2006. 187. Asteraceae Martinov. Flora of North America, 19: 3-69.

Burkhardt, D., 1964. Colour discrimination in insects. Advances in Insect Physiology, 3: 131173.

Cruden, R. W., 1977. Pollen-ovule ratios: A conservative indicator of breeding systems in flowering plants. Evolution, 31: 32-46.
Cruden, R. W., S. M. Hermann, and S. Peterson, 1983. Plant-pollinator coevolution. Pp. 80-125. In: Bentley, B. and T. Elias (eds). The Biology of Nectaries. Columbia University Press, New York.

Dafni, A., P. G. Kevan, and B. C. Husband, 2005. Practical Pollination Biology. Enviroquest Ltd., Cambridge: 590.

De Groot, A. P., 1953. Protein and amino acid requirements of the honey bee (Apis mellifera L.). Physiologia Comparata et Oecologia, 3: 197285.

Gunathilagaraj, K., T. N. A. Perumal., K. Jayaram, and M. Ganesh Kumar, 1998. Field Guide: Some South Indian Butterflies. Niligiri Wildlife and Environmental Association, Niligiri: 274.

Heinrich, B., 1975. Energetics of pollination. Annual Review of Ecology \& Systematics, 6: 139170.

Kingsolver, J. G. and T. L. Daniel, 1979. On the mechanics and energetics of nectar feeding in butterflies. Journal of Theoretical Biology, 76: 167-179.

Kunte, K., 2007. India - A lifescape: Butterflies of Peninsular India. Universities Press, Hyderabad: 254.

Lowry, O. H., N. J. Rosebrough, A. L. Farr, and R. J. Randall, 1951. Protein measurement with the folin phenol reagent. Journal of Biological Chemistry, 193: 265-275.

Powell, A. M., 1965. Taxonomy of Tridax (Compositae). Brittonia, 17: 47-96.

Sadasivam, S. and A. Manickam, 1997. Biochemical Methods. New Age Intl. Pvt. Ltd., New Delhi. 